\title{
Vaginal Abscess
}

National Cancer Institute

\section{Source}

National Cancer Institute. Vaginal Abscess. NCI Thesaurus. Code C35523.

An abscess that is located in the vagina. 